\title{
Impaired Presynaptic Long-Term Potentiation in the Anterior Cingulate Cortex of Fmr1 Knock-out Mice
}

\author{
Kohei Koga, ${ }^{1,2 *}$ Ming-Gang Liu, ${ }^{1,3 \star}$ Shuang Qiu, ${ }^{1,2 *}$ Qian Song, ${ }^{1,2}$ Gerile 0’Den, ${ }^{2}$ Tao Chen, ${ }^{1,2,4}$ and Min Zhuo ${ }^{1,2}$ \\ ${ }^{1}$ Department of Physiology, Faculty of Medicine, University of Toronto, Medical Science Building, Toronto, Ontario, M5S 1A8, Canada, ${ }^{2}$ Center for Neuron \\ and Disease, Frontier Institutes of Science and Technology, Xi' an Jiaotong University, Xi' an, Shanxi 710049, China, ${ }^{3}$ Department of Anatomy and Histology \\ and Embryology, Institute of Medical Sciences, Shanghai Jiao Tong University School of Medicine, Shanghai 200025, China, and ${ }^{4}$ Department of Anatomy \\ and KK Leung Brain Research Center, Fourth Military Medical University, Xi'an, Shanxi 710032, China
}

Fragile X syndrome is a common inherited form of mental impairment. Fragile X mental retardation protein (FMRP) plays important roles in the regulation of synaptic protein synthesis, and loss of FMRP leads to deficits in learning-related synaptic plasticity and behavioral disability. Previous studies mostly focus on postsynaptic long-term potentiation (LTP) in Fmr1 knock-out (KO) mice. Here, we investigate the role of FMRP in presynaptic LTP (pre-LTP) in the adult mouse anterior cingulate cortex (ACC). Low-frequency stimulation induced LTP in layer II/III pyramidal neurons under the voltage-clamp mode. Paired-pulse ratio, which is a parameter for presynaptic changes, was decreased after the low-frequency stimulation in Fmr1 wild-type (WT) mice. Cingulate pre-LTP was abolished in Fmr1 KO mice. We also used a 64-electrode array system for field EPSP recording and found that the combination of low-frequency stimulation paired with a GluK1-containing kainate receptor agonist induced NMDA receptor-independent and metabotropic glutamate receptordependent pre-LTP in the WT mice. This potentiation was blocked in Fmr1 KO mice. Biochemical experiments showed that Fmr1 K0 mice displayed altered translocation of protein kinase A subunits in the ACC. Our results demonstrate that FMRP plays an important role in pre-LTP in the adult mouse ACC, and loss of this pre-LTP may explain some of the behavioral deficits in Fmr1 KO mice.

Key words: cortex; FMRP; fragile X disease; LTP; mice; PKA

\section{Introduction}

Fragile X syndrome (FXS) is the most common inherited mental retardation and cause of autism (Bhakar et al., 2012). This disease is caused by the expansion of a trinucleotide repeat (CGG) within the X-linked fragile X mental retardation 1 (Fmrl) gene (Bagni and Greenough, 2005; Bhakar et al., 2012). Due to the expansion, fragile X mental retardation protein (FMRP), which is the product of the Fmrl gene, is not expressed (Santoro et al., 2012). FMRP is located in both presynaptic and postsynaptic compartments in the CNS (Christie et al., 2009; Akins et al., 2012; Zang et al., 2013). FMRP has been suggested as an important messenger for synaptic functions (Santoro et al., 2012). Loss of FMRP can lead to deficits in long-term synaptic plasticity and contributes to

\footnotetext{
Received June 29, 2014; revised Nov. 24, 2014; accepted Dec. 18, 2014.

Author contributions: K.K., S.Q., and M.Z. designed research; K.K., M.-G.L., S.Q., Q.S., G.O., and T.C. performed research; K.K., S.Q., Q.S., G.O., T.C., and M.Z. analyzed data; K.K., M.-G.L., S.Q., and M.Z. wrote the paper.

This work was supported by grants from the ELLB-CIHR Michael Smith Chair in Neurosciences and Mental Health, Canada Research Chair, Canadian Institute for Health Research operating Grants (MOP-124807), NSERC Discovery Grant (RGPIN 402555), and the Azrieli Neurodevelopmental Research Program and Brain Canada. K.K., S.Q., and T.C. are supported by the postdoctoral fellowship from Fragile X research foundation of Canada.

${ }^{*}$ K.K., M.-G.L., and S.Q. contributed equally to this work.

The authors declare no competing financial interests.

Correspondence should be addressed to Min Zhuo, Department of Physiology, Faculty of Medicine, University of Toronto, Medical Science Building, Room 3342, 1 King's College Circle, Toronto, ON M5S 1A8, Canada. E-mail: min.zhuo@utoronto.ca.

DOI:10.1523/JNEUROSCI.2644-14.2015

Copyright $\odot 2015$ the authors $\quad 0270-6474 / 15 / 352033-11 \$ 15.00 / 0$
}

abnormal cognitive behaviors in fragile $\mathrm{X}$ patients and rodents (Bhakar et al., 2012; Santoro et al., 2012).

Long-term potentiation (LTP) is a major type of long-lasting synaptic plasticity and is associated with learning and memory (Bliss and Collingridge, 1993; Kandel, 2012). LTP is expressed either postsynaptically or presynaptically in the brain (Bortolotto et al., 1999; Nicoll and Schmitz, 2005; Bliss and Collingridge, 2013). It has been known that FMRP contributes to postsynaptic LTP (post-LTP) induction in the anterior cingulate cortex (ACC) (Zhao et al., 2005; Chen et al., 2014b), whereas the role of FMRP in hippocampal LTP is still controversial (Godfraind et al., 1996; Paradee et al., 1999; Hu et al., 2008; Shang et al., 2009).

Recent studies indicate that FMRP may contribute to presynaptic plasticity (Deng et al., 2011; Wang et al., 2014). However, it is still unclear whether FMRP could contribute to the induction of presynaptic form of LTP (pre-LTP) in the cortex. In this study, we investigated the possibility of pre-LTP induction in the ACC of adult mice and found that low-frequency stimulation can produce a novel form of cingulate pre-LTP in Fmr1 wild-type (WT) mice. Pre-LTP can also be induced by combining low-frequency stimulation with a GluK1-containing kainate receptor agonist in 64-channel field potential recordings. Induction of both types of pre-LTP is blocked in Fmrl knock-out (KO) mice. Finally, we show that deletion of Fmrl can cause translocations of protein kinase A (PKA) subunits in the ACC, which may partially contribute to the loss of pre-LTP. 


\section{Materials and Methods}

Animals. Adult male Fmrl WT and KO mice (8- to 12-wk-old) were obtained as gifts from Dr W. T. Greenough (University of Illinois, Champaign, IL). All mice were maintained on a $12 \mathrm{~h}$ light/dark cycle (temperature $22-26^{\circ} \mathrm{C}$, air humidity 55-60\%) with food and water provided ad libitum. The Animal Care and Use Committee at the University of Toronto and $\mathrm{Xi}$ 'an Jiaotong University approved the experimental protocols. All experiments related to mutant mice were performed blind to the genotype.

Whole-cell patch-clamp recordings in the ACC neurons. Experimental procedures are based on those described previously (Zhao et al., 2005; Descalzi et al., 2013). Briefly, mice were anesthetized with $1-2 \%$ isoflurane. Coronal slices of the ACC $(300 \mu \mathrm{m})$ were prepared using standard methods. Slices were transferred to a room temperature-submerged recovery chamber with an oxygenated (95\% $\mathrm{O}_{2}-5 \% \mathrm{CO}_{2}$ ) artificial CSF (ACSF) containing the following (in mM): $124 \mathrm{NaCl}, 25 \mathrm{NaHCO}_{3}$, $2.5 \mathrm{KCl}, 1 \mathrm{KH}_{2} \mathrm{PO}_{4}, 2 \mathrm{CaCl}_{2}, 2 \mathrm{MgSO}_{4}$, and 10 glucose. After a $1 \mathrm{~h}$ recovery period, slices were transferred into a recording chamber on the stage of an Axioskop 2FS microscope (Zeiss) equipped with infrared DIC optics for visualized recordings. The evoked EPSCs (eEPSCs) were recorded with an Axon 200B amplifier (Molecular Devices) and stimulation was delivered by a bipolar tungsten-stimulating electrode placed in layer V/VI of the ACC. Control test pulses (paired-pulse at $50 \mathrm{~ms}$ interval) were given every $30 \mathrm{~s}$. For the induction of pre-LTP, repetitive low-frequency stimulation was delivered at $2 \mathrm{~Hz}$ for $2 \mathrm{~min}$. Paired-pulse ratio (PPR) was also monitored to see any presynaptic change caused by low-frequency stimulation. In the voltage-clamp configuration, recording electrodes $(2-5 \mathrm{M} \Omega$ ) contained the pipette solution composed of the following (in mM): 120 K-gluconate, $5 \mathrm{NaCl}, 1 \mathrm{MgCl}_{2} 0.5$ EGTA, 2 Mg-ATP, $0.1 \mathrm{Na}_{3} \mathrm{GTP}$, and 10 HEPES, pH 7.2, 280-300 mOsm. The initial access resistance was $15-30 \mathrm{M} \Omega$, and it was monitored throughout the experiment. Data were discarded if the access resistance changed $>15 \%$ during experiment. Data were filtered at $1 \mathrm{kHz}$, and digitized at $10 \mathrm{kHz}$. The membrane potential was held at $-60 \mathrm{mV}$ throughout the experiment. Data were collected and analyzed with Clampex and Clampfit 10.2 software (Molecular Devices).

Multielectrode array recordings in the ACC slices. Coronal brain slices containing the ACC $(300 \mu \mathrm{m})$ were obtained as previously described (Chen et al., 2014a; Liu and Zhuo, 2014). After cutting, slices were then incubated in a submerged recovery chamber with oxygenated $\left(95 \% \mathrm{O}_{2}\right.$ and $\left.5 \% \mathrm{CO}_{2}\right)$ ACSF containing the following (in mM): $124 \mathrm{NaCl}, 4.4 \mathrm{KCl}, 2 \mathrm{CaCl}_{2}, 1 \mathrm{MgSO}_{4}, 25 \mathrm{NaHCO}_{3}, 1$ $\mathrm{NaH}_{2} \mathrm{PO}_{4}$, and 10 glucose, $\mathrm{pH}$ 7.2-7.4, at room temperature for at least 2 h. The MED64 probe (P515A, Panasonic Alpha-Med Sciences) has an array of 64 planar microelectrodes, arranged in an $8 \times 8$ pattern, with an interpolar distance of $150 \mu \mathrm{m}$. Before use, the surface of the MED64 probe was treated with $0.1 \%$ polyethylenimine (Sigma-Aldrich, P-3143) in $25 \mathrm{~mm} / \mathrm{L}$ borate buffer, $\mathrm{pH} 8.4$, overnight at room temperature. The

E

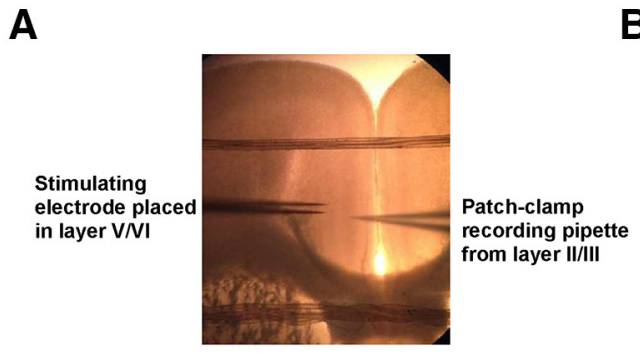

B Whole-cell patch-clamp recording
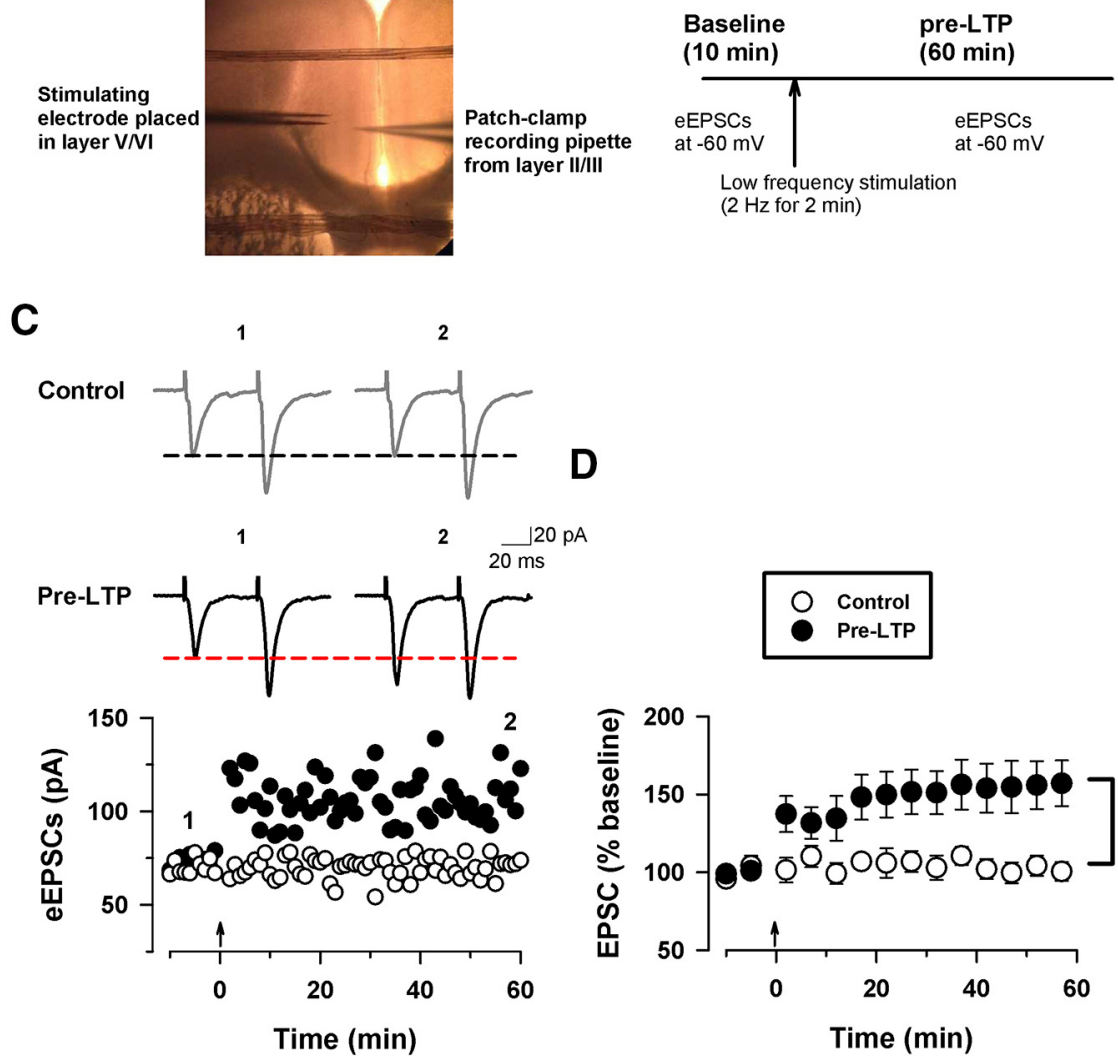

$\mathbf{F}$

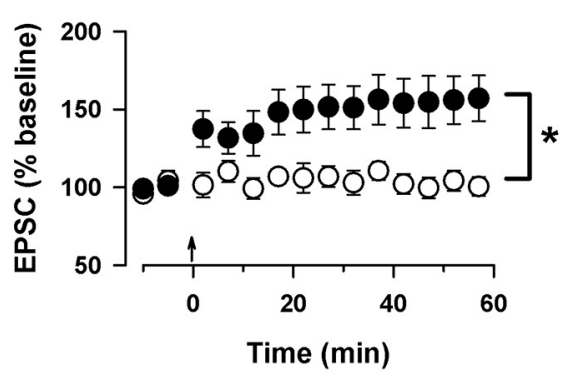

Figure 1. Pre-LTP in the ACC neurons of Fmr 1 WT mice obtained with whole-cell patch-clamp recording. A, Schematic diagram showing the recording setup. We placed the recording electrode in layer II/III pyramidal neurons and the stimulation electrode in layer V/VI of the adult mouse ACC slice. $\boldsymbol{B}$, Experimental procedure for pre-LTP recording. C, Delivery of low-frequency stimulation $(2 \mathrm{~Hz}, 2 \mathrm{~min}$ ) induced LTP that lasted for $1 \mathrm{~h}$ (black circle), whereas control stimulation without low-frequency stimulation did not cause LTP (white circle) in one single neuron. Sample traces at the indicated time points are shown above the plot. Calibration, 20 PA, $20 \mathrm{~ms}$. $D$, Summarized data showing the induction of pre-LTP by low-frequency stimulation ( $n=8$ neurons $/ 8$ mice) compared with control group ( $n=8$ neurons/8 mice). $\boldsymbol{E}$, Raw values of PPR for the neurons shown in $\boldsymbol{C}$. The low-frequency stimulation reduced the PPR (black triangle), whereas control stimulation could not change the PPR (white triangle). $\boldsymbol{F}$, Summarized data of PPR in 8 neurons from 8 mice. Error bars are SEM; ${ }^{*} p<0.05$.

probe surface was routinely rinsed three to five times with sterile distilled water before immediate use in each experiment (Liu et al., 2013a). After incubation, one slice was transferred to the recording chamber and perfused with $\mathrm{ACSF}$ at $28-30^{\circ} \mathrm{C}$ and maintained at a $2 \mathrm{ml} / \mathrm{min}$ flow rate. The slices were positioned on the MED64 probe to cover the different layers of the ACC (Chen et al., 2014a; Liu and Zhuo, 2014). One of the channels located in the layer V/VI was then chosen as the stimulation site. Monopolar and biphasic constant current pulse (10-20 $\mu \mathrm{A}, 0.2 \mathrm{~ms})$ was applied to the stimulation channel and the intensity was adjusted so that a half-maximal field EPSP (fEPSP) was elicited in the channels closest to 
the stimulation site. The channels with fEPSP were considered as active channels and their responses were sampled every $2 \mathrm{~min}$. Baseline responses were first recorded until the baseline response variation is $<5 \%$ in most of the active channels within $1 \mathrm{~h}$. Then, in the presence of the NMDA receptor antagonist (AP5, $50 \mu \mathrm{M}, 38 \mathrm{~min}$ ), low-frequency stimulation $(2 \mathrm{~Hz}, 2 \mathrm{~min})$ with a selective GluK1-containing kainate receptor agonist (ATPA, $1 \mu \mathrm{M}, 18 \mathrm{~min}$ ) was applied to the same stimulation site to induce pre-LTP. After low-frequency stimulation, the test stimulus was repeatedly delivered once every $2 \mathrm{~min}$ for $1 \mathrm{~h}$ to monitor the time course of pre-LTP.

Western blot analysis. Subcellular fractionation was conducted on tissue from Fmr1 WT or KO mice using an adapted protocol (Qiu et al., 2013, 2014). Cortices were dissected on ice in cold ACSF and homogenized in $0.32 \mathrm{~m}$ sucrose buffer ( $10 \mathrm{~mm}$ sucrose, 10 mM HEPES, pH 7.4) containing a protease inhibitor cocktail $(\mathrm{H}$, homogenate). Samples were centrifuged $\left(1000 \times \mathrm{g}, 10 \mathrm{~min}, 4^{\circ} \mathrm{C}\right)$ to yield the nuclear enriched pellet and the $\mathrm{S} 1$ fraction. The $\mathrm{S} 1$ fraction was then centrifuged $(12,000 \times \mathrm{g}, 20$ min, $4^{\circ} \mathrm{C}$ ) to obtain the pellet (P2; crude synaptosomal membranes) fraction and supernatant fraction (S2, cytosome). The H, S2, and P2 samples were stored at $-80^{\circ} \mathrm{C}$ until use. Western blotting was conducted as described previously (Wang et al., 2008; Qiu et al., 2013). Protein concentration was measured with the Bradford assay. Electrophoresis of equal amounts of total protein was performed on SDS-polyacrylamide gels. Separated proteins were transferred onto polyvinylidene fluoride membranes at $4^{\circ} \mathrm{C}$. The membranes were blocked $[2 \mathrm{~h}$, room temperature, $5 \%$ milk or $5 \%$ bovine serum albumin (BSA) in TBST (tris-buffered saline with Tween 20)] and incubated with primary antibody (5\% BSA in TBST, $4^{\circ} \mathrm{C}$ overnight). After being washed, the membranes were incubated with the appropriate HRP-coupled secondary antibody diluted 1:3000 for $1 \mathrm{~h}$, followed by enhanced chemiluminescence detection of the proteins with Western lightning Chemiluminescence Reagent Plus (PerkinElmer) according to the instructions of the manufacturer. To verify equal loading, we also probed the membranes with an antibody against actin. The density of the immunoblots was measured with the National Institutes of Health ImageJ program.

Drugs and antibodies. Protease inhibitor cocktail and antibodies against actin (A2066, 1:1000) were purchased from Sigma-Aldrich. Antibodies against PKA RII $\alpha$ (ab38946, 1:1000), PKA RII $\beta$ (ab75993, $1: 1000)$, and synapsin I (ab8, 1:1000) were purchased from Abcam. Antibody against AKAP79/150 (sc-10765, 1:2000) was purchased from Santa Cruz Biotechnology. HRP-linked goat anti-mouse IgG and goat anti-rabbit IgG for Western blot were purchased from Millipore. All chemicals and drugs were obtained from Tocris Cookson. D(-)-2amino-5-phosphonopentanoicacid (AP5), (+)- $\alpha$-methyl-4-carboxylphenlyglycine (MCPG), and amino-3-(3-hydroxy-5-tert-butylisoxazol-4-yl) propanoic acid (ATPA) were dissolved in distilled water, and nimodipine was prepared in dimethyl sulfoxide as stock solutions for frozen aliquots at $-20^{\circ} \mathrm{C}$. All of these drugs were diluted from the stock solutions to the final desired concentration in the ACSF before immediate use. The dimethyl sulfoxide diluted in ACSF had no effect on basal synaptic transmission and plasticity.

Data analysis. Whole-cell patch-clamp data were collected and analyzed with Clampex 10.2 and Clampfit 10.2 software (Molecular Devices). All multichannel electrophysiological data were analyzed off-line by the MED64 Mobius software. For quantification of the LTP data, the initial slope of fEPSP was measured by taking the rising phase between $10 \%$ and $90 \%$ of the peak response, normalized and expressed as percentage change from the baseline level. The number of activated channels $(>20 \%$ of baseline; that is, the amplitude goes over $-20 \mu \mathrm{V})$ versus the channels showing LTP (increased by at least $20 \%$ of baseline) was also counted and presented as the induction ratio of LTP (number of LTPoccurring channels/number of all activated channels $\times 100 \%$ ). For the PPR, the ratio of the slope of the second response to the slope of the first response was calculated and averaged. For comparison between two groups, we used paired or unpaired Student's $t$ test. For comparison among three groups, we used one-way ANOVA. For Western blot analysis, statistical analysis of differences between two groups was tested by unpaired, two-tailed Student's $t$ test or Mann-Whitney rank sum test, based on the normality test (Shapiro-Wilk) of the data. All data are

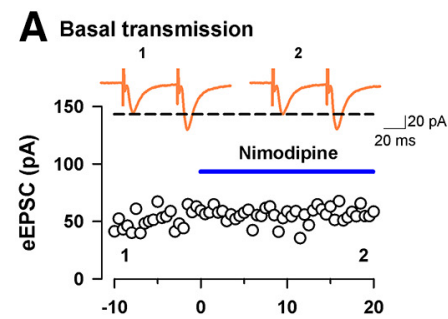

B

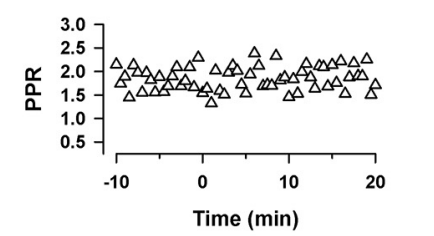

C Induction of pre-LTP

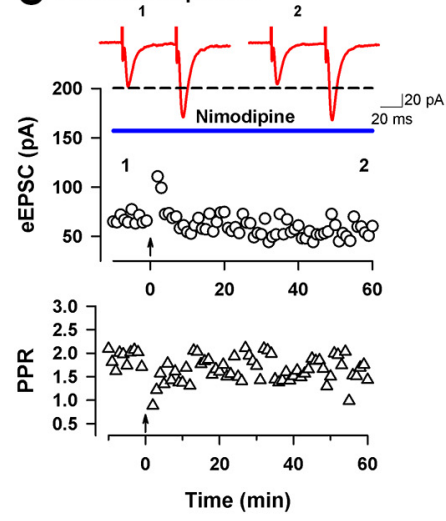

E Maintenance of pre-LTP
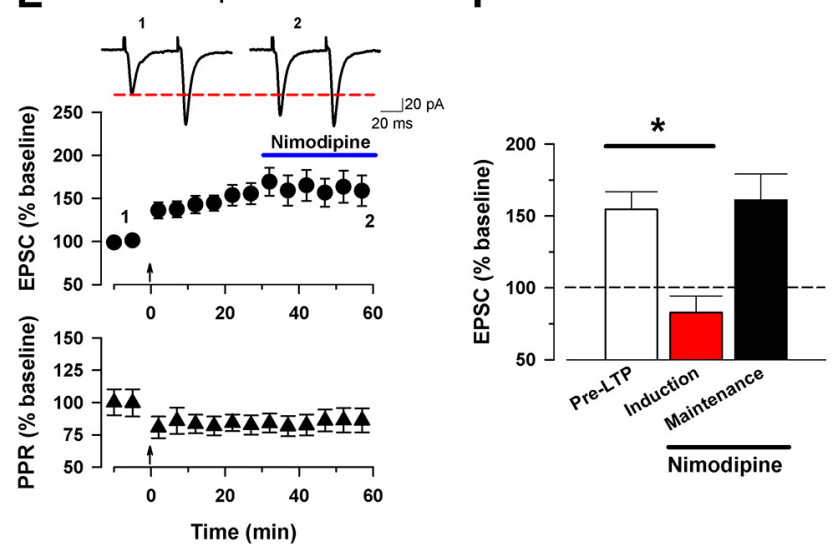

Figure 2. Induction of cingulate pre-LTP requires L-VGCC. $A$, Bath application of nimodipine $(10 \mu \mathrm{M})$ has no effect on basal synaptic transmission and PPR in one neuron. $\boldsymbol{B}$, Pooled data of nine neurons from seven mice. $C$, Infusion of nimodipine blocked the induction of pre-LTP in one neuron (top). PPR was not changed in the same neuron (bottom). $\boldsymbol{D}$, Pooled data of eight neurons from eight mice. $\boldsymbol{E}$, Nimodipine did not affect the maintenance of pre-LTP when applied $30 \mathrm{~min}$ after low-frequency stimulation ( $n=9$ neurons/7 mice, top). PPR remained decreased to the end of recording (bottom). $\boldsymbol{F}$, Summary of the effect of nimodipine on the induction and maintenance of pre-LTP. Insets in $A, C$, and $E$ are example eEPSC traces at time points indicated by the numbers in the graph. Calibration, 20 pA, 20 ms. Error bars are SEM; ${ }^{*} p<0.05$.

presented as means \pm SEM. In all cases, $p<0.05$ was considered statistically significant.

\section{Results}

Low-frequency stimulation induces pre-LTP in the ACC of Fmr1 WT mice

To explore the possibility of pre-LTP induction in the ACC, we performed whole-cell patch-clamp recordings from pyramidal 
neurons in layer II/III, where the stimulation electrodes were placed in layer V/VI (Fig. 1A). We recorded eEPSCs with paired-pulse at a $50 \mathrm{~ms}$ interval. The membrane potential was held at $-60 \mathrm{mV}$ and the amplitude of first eEPSCs was adjusted at 50-100 pA. The PPR was monitored during the entire recording session to see any presynaptic alteration (Zucker and Regehr, 2002). We adopted the previous protocol for inducing pre-LTP in the amygdala (Shin et al., 2010). Figure $1 B$ showed the experimental procedure. After recording stable baseline eEPSCs for at least $10 \mathrm{~min}$, we delivered an lowfrequency stimulation protocol $(2 \mathrm{~Hz}, 2$ min, membrane potential held at -60 $\mathrm{mV}$ ) and then recorded eEPSCs for $1 \mathrm{~h}$. As expected, low-frequency stimulation produced a significant, long-lasting potentiation of synaptic responses in the Fmrl WT mice $(151 \pm 15 \%$ of baseline at $1 \mathrm{~h}$ after low-frequency stimulation; $n=8$ neurons $/ 8$ mice, paired $t$ test, $p<0.05$; Fig. $1 C, D)$. The averaged PPR at $50 \mathrm{~ms}$ interval in the baseline period was $1.5 \pm 0.1$, which is similar as reported previously (Zhao et al., 2005). The low-frequency stimulation caused a significant reduction in the PPR (75 $\pm 8 \%$ of baseline, $n=8$ neurons $/ 8$ mice, paired $t$ test, $p<0.05$; Fig. $1 E, F)$. As a control group, we recorded eEPSCs without giving the low-frequency stimulation (Fig. $1 C, D)$. In this case, no LTP was detected $(101 \pm 6 \%$ of baseline, $n=8$ neurons/ 8 mice, paired $t$ test, $p>0.05$; Fig. $1 D)$. PPR did not change $1 \mathrm{~h}$ after the recording without low-frequency stimulation application $(101 \pm 8 \%$ of baseline, $n=8$ neurons $/ 8$ mice, paired $t$ test, $p>0.05$; Fig. $1 F$ ). These results suggest that low-frequency stimulation application can produce a clear pre-LTP in the ACC.

\section{L-VGCC is required for the induction of cingulate pre-LTP}

The voltage-gated calcium channels (VGCCs) are well known to regulate neurotransmitter release and contribute to pre-LTP in the hippocampus (Lauri et al., 2003; Nicoll and Schmitz, 2005) and amygdala (Fourcaudot et al., 2009). Therefore, we tested whether L-VGCC is involved in cingulate pre-LTP induction. Bath application of an L-VGCC inhibitor, nimodipine (10 $\mu \mathrm{M})$, had no effect on basal synaptic transmission ( $94 \pm 9 \%$ of baseline, $n=9$ neurons $/ 7$ mice, paired $t$ test, $p>0.05$; Fig. $2 A, B$ ). This finding is consistent with our recent publication (Kang et al., 2013). Next, we studied whether nimodipine could affect the induction of pre-LTP. Delivery of low-frequency stimulation in the presence of nimodipine failed to induce pre-LTP $(83 \pm 12 \%$ of baseline at $1 \mathrm{~h}$ after low-frequency stimulation; $n=8$ neurons/ 8 mice; $p>0.05$; Fig. $2 C, D$, top). The PPR was also unal-

A

C ${ }^{*} p<0.05$.

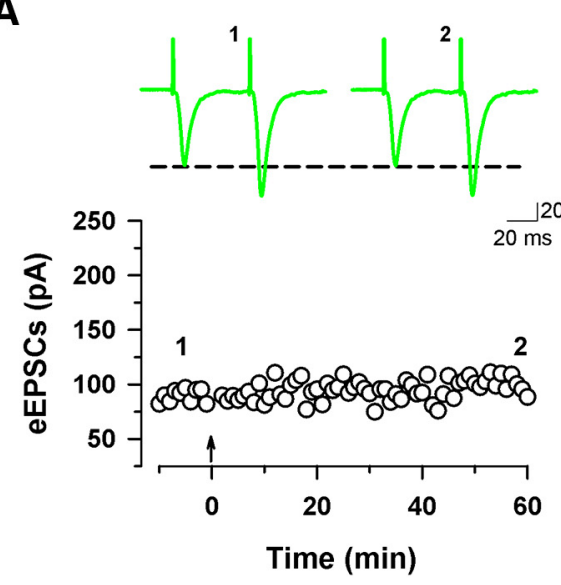

B
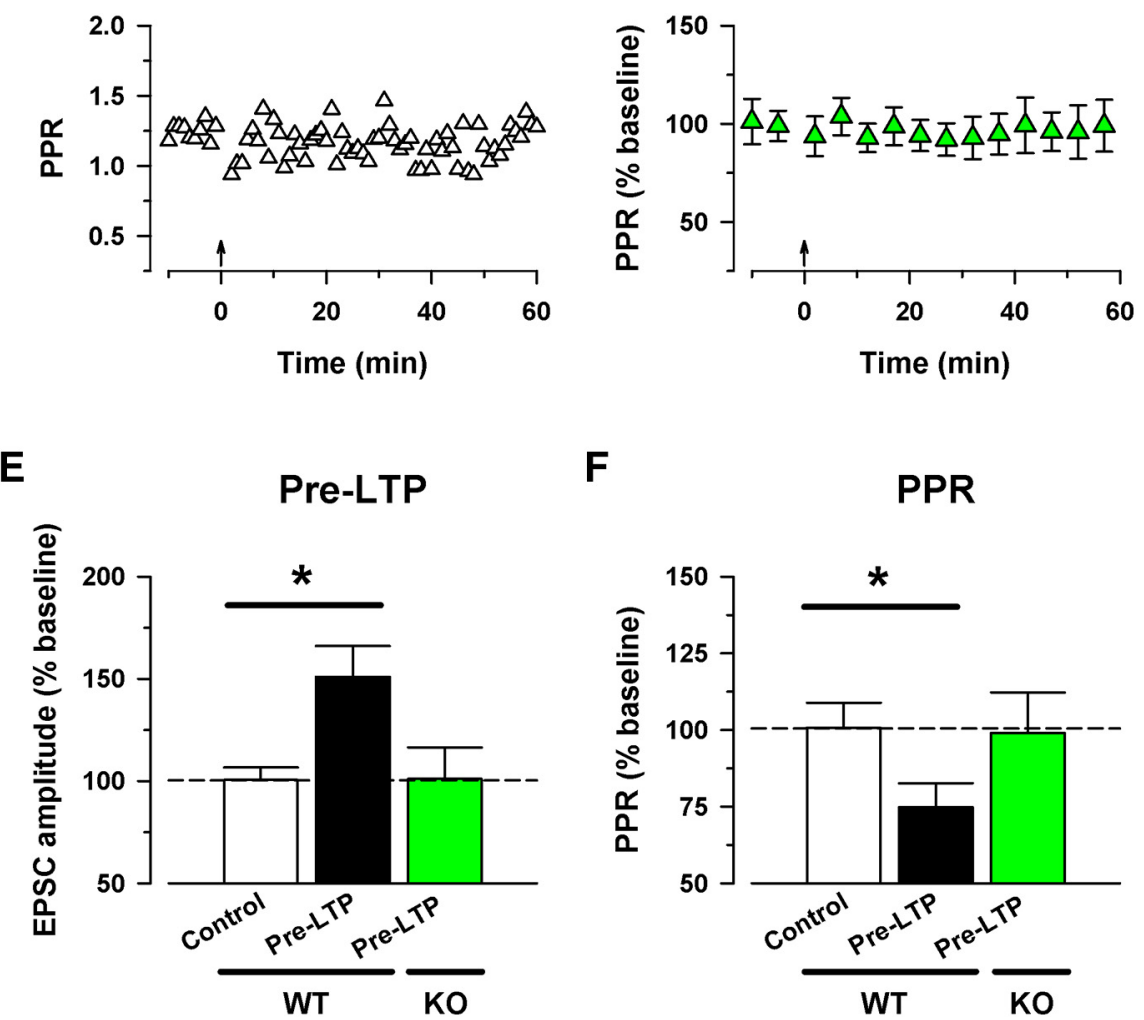

Figure 3. Loss of pre-LTP in the ACC of $F m r 1 \mathrm{KO}$ mice. $A$, The low-frequency stimulation failed to induce pre-LTP in one neuron of the $F m r 1 \mathrm{KO}$ mice. Sample traces at the indicated time points are shown above the plot. Calibration, $20 \mathrm{pA}, 20 \mathrm{~ms}$. $\boldsymbol{B}$, Averaged plots for the loss of pre-LTP induction in the Fmr $1 \mathrm{KO}$ mice ( $n=8$ neurons $/ 8$ mice). C, PPR was unaltered by low-frequency stimulation in one neuron of $F m r 1$ KO mice. $\boldsymbol{D}$, Averaged plots for PPR ( $n=8$ neurons $/ 8$ mice). $\boldsymbol{E}$, Summary of pre-LTP data in Fmr 1 WT and Fmr 1 KO mice. $\boldsymbol{F}$, Summary of PPR data in Fmr 1 WT and Fmr 1 KO mice. Error bars are SEM;

tered by low-frequency stimulation when nimodipine was bath applied throughout the entire recording period (Fig. $2 C, D$, bottom). We further tested whether the maintenance of pre-LTP requires L-VGCC. Established pre-LTP was insensitive to nimodipine when given $30 \mathrm{~min}$ after low-frequency stimulation $(155 \pm 12 \%$ of baseline at $30 \mathrm{~min}$ after pre-LTP, $164 \pm 19 \%$ of baseline in $30 \mathrm{~min}$ after nimodipine, $n=9$ neurons $/ 7$ mice, $p<$ 0.05 compared with baseline; Fig. $2 E$ ). These findings indicate that L-VGCC is required for the induction but not maintenance of pre-LTP in the ACC (Fig. $2 F$ ). 

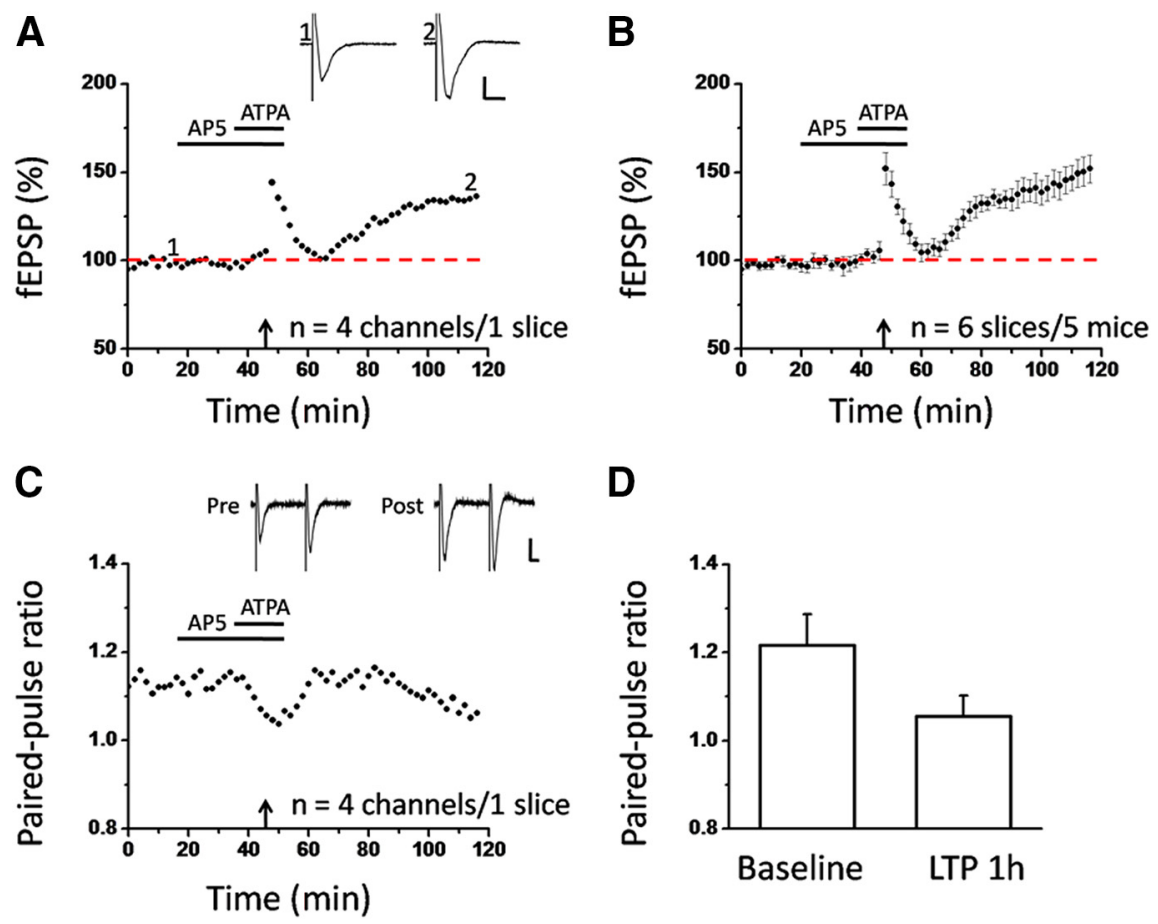

$\mathbf{E}$

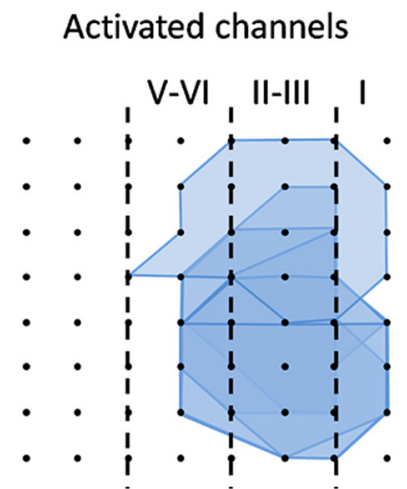

D

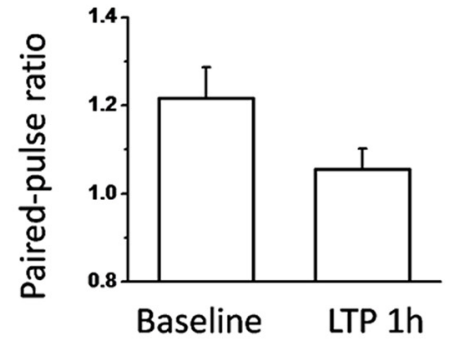

$\mathbf{F}$

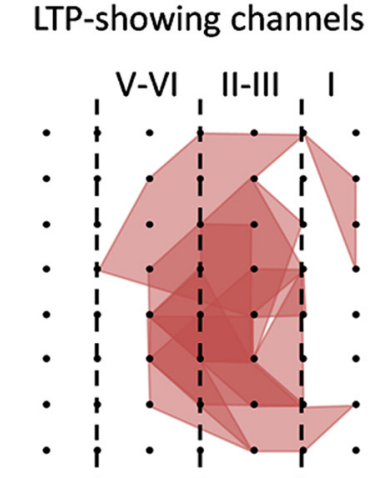

Figure 4. Pre-LTP in the ACC network of Fmr 1 WT mice obtained with multichannel field potential recording. $A$, Low-frequency stimulation ( $2 \mathrm{~Hz}, 2 \mathrm{~min}$ ) combined with ATPA (1 $\mu \mathrm{m}, 18 \mathrm{~min}$ ) resulted in NMDA receptor-independent LTP that lasted for $1 \mathrm{~h}$ in one slice (averaged data of 4 channels). B, Pooled data from six slices of five mice. C, PPR was decreased $1 \mathrm{~h}$ after the low-frequency stimulation plus ATPA in one slice (averaged data of 4 channels). $\boldsymbol{D}$, Bar histogram showing the pooled data of PPR from six slices of five mice. $\boldsymbol{E}, \boldsymbol{F}$, Polygonal diagrams of the channels that are activated in the baseline (blue, $\boldsymbol{E}$ ) and that undergo pre-LTP (red, $\boldsymbol{F}$ ) in six slices from five mice. Most of the activated channels exhibited pre-LTP, spreading to all layers of the ACC. Insets in A show representative fEPSP traces at time points indicated by the numbers in the graph. Sample traces in $\mathrm{C}$ are paired-pulse responses before (Pre) and $1 \mathrm{~h}$ after pre-LTP induction (Post). Calibration, $50 \mu \mathrm{V}$, $10 \mathrm{~ms}$. Error bars are SEM; ${ }^{*} p<0.05$.

\section{Fmr1 KO mice show loss of cingulate pre-LTP}

Previously, we found that Fmr1 KO mice displayed normal basal transmissions, and impaired post-LTP induction in the ACC (Zhao et al., 2005; Chen et al., 2014b). To determine whether pre-LTP is equally vulnerable to Fmrl deletion, we gave the same low-frequency stimulation protocol in the ACC slices obtained from Fmr1 KO mice (Fig. 3). The low-frequency stimulation failed to induce any significant pre-LTP from a single neuron (Fig. $3 A$ ) or pooled data ( $101 \pm 15 \%$ of baseline, $n=8$ neurons $/ 8$ mice, paired $t$ test, $p>0.05$; Fig. $3 B$ ). PPR was not changed after low-frequency stimulation ( $97 \pm 15 \%$ of baseline, $n=8$ neurons $/ 8$ mice, paired $t$ test, $p>0.05$; Fig. $3 C, D)$. These results suggest that FMRP plays an important role in the induction of pre-LTP in the ACC (Fmrl WT control group: $n=8$ neurons/ 8 mice, Fmr 1 WT pre-LTP group: $n=8$ neurons/ 8 mice, Fmr $1 \mathrm{KO}$
pre-LTP group: $n=8$ neurons/ 8 mice, one-way ANOVA, $p<0.05$ in pre-LTP, $p<0.05$ in PPR; Fig. $3 E, F)$.

\section{Multichannel recordings of pre-LTP in the ACC circuit}

To characterize the cingulate pre-LTP at the network level, we used a 64-channel recording system to map cortical circuit responses within the ACC in response to focal electrical stimulation in the deep layer (Kang et al., 2012; Chen et al., 2014a). After the baseline response was stabilized for $20 \mathrm{~min}$, we bath applied AP5 $(50 \mu \mathrm{M})$ for $20 \mathrm{~min}$, before applying lowfrequency stimulation $(2 \mathrm{~Hz}, 2 \mathrm{~min})$ in the presence of a GluK1-containing kainate receptor agonist (ATPA, $1 \mu \mathrm{M}, 18 \mathrm{~min}$ ). The low-frequency stimulation was delivered 8 min after the onset of ATPA application. AP5 was always present during the pre-LTP induction process to exclude any contribution of postsynaptic influences. We found that the combination of lowfrequency stimulation with ATPA produced LTP lasting for at least $1 \mathrm{~h}$ (Fig. 4A). Analysis of one single slice revealed that the response was potentiated to $136 \%$ of baseline at $1 \mathrm{~h}$ after low-frequency stimulation. Pooled data are presented in Figure $4 B(152 \pm 8 \%$ of baseline, $n=6$ slices $/ 5$ mice, paired $t$ test, $p<0.001$ compared with baseline). We also evaluated changes in the PPR and found that low-frequency stimulation together with ATPA significantly reduced the PPR at $50 \mathrm{~ms}$ interval (baseline vs $1 \mathrm{~h}$ after LTP induction: $1.2 \pm$ 0.1 vs $1.0 \pm 0.1, n=6$ slices $/ 5$ mice, paired $t$ test, $p<0.05$ compared with baseline; Fig. $4 C, D$ ), suggesting the presynaptic locus of LTP expression.

In addition to the time course, we also analyzed the spatial distribution of preLTP-showing channels across the ACC circuit. The numbers of activated channels and pre-LTP-occurring channels were counted for each slice. We used the blue lines to represent the activated channels (Fig. $4 E$ ) and the red lines (Fig. $4 F$ ) to denote the pre-LTPshowing channels. In total, 106 channels (mean \pm SEM: $18 \pm 1$ ) exhibited clear synaptic responses from six slices, with 70 channels (mean \pm SEM: $12 \pm 1$ ) undergoing LTP. The induction ratio of pre-LTP is $66 \pm 6 \%$. Also, the LTP-occurring channels spread to both layer II/III and layer V/VI (Fig. $4 F$ ). These findings suggest that low-frequency stimulation delivery coupled with GluK1 receptor activation could produce NMDA receptor-independent pre-LTP in the ACC.

\section{Low-frequency stimulation or ATPA alone fails to induce} cingulate pre-LTP at the network level

Next we tested whether low-frequency stimulation or ATPA alone could produce potentiation. The low-frequency stimulation alone in the presence of AP5 $(50 \mu \mathrm{M})$ failed to induce any 
potentiation $(107 \%$ of baseline at $1 \mathrm{~h}$ after low-frequency stimulation, $n=4$ channels/ 1 slice; Fig. $5 A ; 106 \pm 3 \%$ of baseline, $n=6$ slices $/ 5$ mice, $p>0.05$; Fig. $5 B$ ). Accordingly, the PPR was also not affected (baseline vs $1 \mathrm{~h}$ after low-frequency stimulation: $1.5 \pm 0.1$ vs $1.4 \pm 0.1, n=6$ slices/5 mice; Fig. $5 C, D$ ). In the second set of experiments, we treated the ACC slice with ATPA $(1 \mu \mathrm{M})$ for $30 \mathrm{~min}$ without low-frequency stimulation and recorded fEPSP for 40 min after ATPA washout. We found that ATPA alone could not elicit any potentiation of the synaptic responses $(100 \%$ of baseline at $40 \mathrm{~min}$ after ATPA, $n=4$ channels/ 1 slice; Fig. $6 A$; $100 \pm 3 \%$ of baseline, $n=5$ slices $/ 5$ mice, $p>0.05$; Fig. $6 B$ ). ATPA did not affect the PPR (baseline vs 40 min after ATPA: $1.2 \pm$ 0.1 vs $1.1 \pm 0.1, n=5$ slices $/ 5$ mice; Fig. $6 C, D)$.

Activation of $\mathrm{mGluR}$ is required for inducing cingulate pre-LTP at the network level

Given the previous demonstration that hippocampal mossy fiber pre-LTP is regulated by both kainate receptor and metabotropic glutamate receptor (mGluR; Nisticò et al., 2011), we examined whether cingulate pre-LTP requires the activation of imGluR. We perfused the ACC slice with an mGluR antagonist, MCPG (500 $\mu \mathrm{M})$ at the same time with AP5. We found that MCPG abolished the induction of pre-LTP ( $100 \pm 2 \%$ of baseline at $1 \mathrm{~h}$ after low-frequency stimulation, $n=6$ slices $/ 6$ mice; Fig. 7A). Consistently, the PPR was not significantly affected by low-frequency stimulation in the presence of MCPG (Fig. $7 B$ ). In addition, MCPG also blocked cingulate pre-LTP spatially (Fig. $7 C, D$ ). Specifically, there are a total of 93 channels (mean \pm SEM: $4.2 \pm 1.1$ ) being activated from the six slices included in the spatial analysis, but only 25 channels (mean \pm SEM: $15.5 \pm 1.0$ ) showed preLTP, with the induction ratio being $26.9 \pm 7.6 \%$ ( $n=6$ slices $/ 6$ mice $)$. These data suggest that pre-LTP induced by lowfrequency stimulation combined with ATPA is mGluR-dependent.

Fmr1 KO mice could not undergo preLTP in the ACC network

Next we examined the network properties of pre-LTP in Fmr1 KO mice. Similar to the whole-cell recordings, multichannel fEPSP recordings revealed an impairment of pre-LTP in the ACC network. Figure $8 A, B$ illustrates the averaged data of five channels in one slice and pooled data from six slices, respectively. There is no
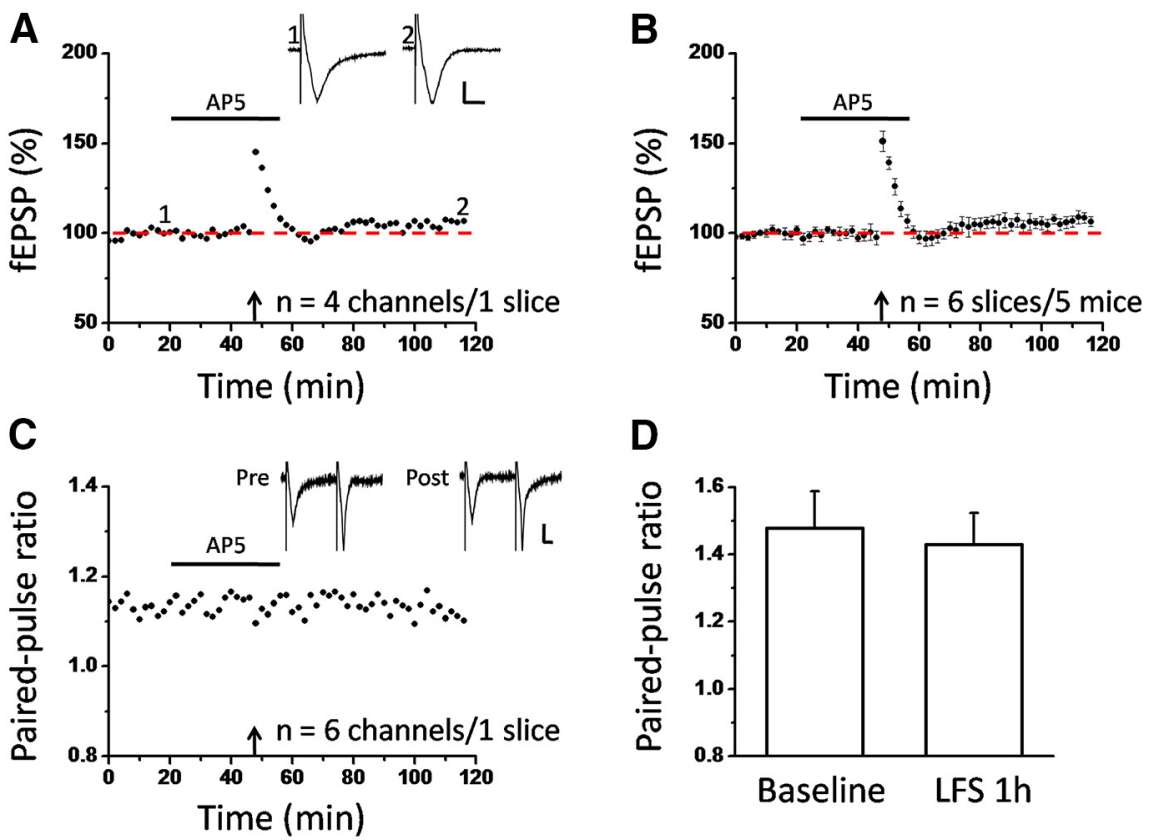

Figure 5. Low-frequency stimulation alone cannot induce cingulate pre-LTP at the network level. $A$, Low-frequency stimulation ( $2 \mathrm{~Hz}, 2 \mathrm{~min})$ was given in the presence of AP5 $(50 \mu \mathrm{m})$ but without concomitant ATPA application. Results of four channels in one slice (averaged data of 4 channels) showed the failure of pre-LTP induction. $\boldsymbol{B}$, Pooled data from six slices of five mice. C, PPR remains unaffected by low-frequency stimulation alone in one slice (averaged data of 6 channels). $\boldsymbol{D}$, Bar histogram showing the pooled data of PPR from six slices of five mice. Insets in $\boldsymbol{A}$ show representative fEPSP traces at time points indicated by the numbers in the graph. Sample traces in $C$ are paired-pulse responses before (Pre) and $1 \mathrm{~h}$ after low-frequency stimulation (Post). Calibration, $50 \mu \mathrm{V}, 10 \mathrm{~ms}$. Error bars are SEM.
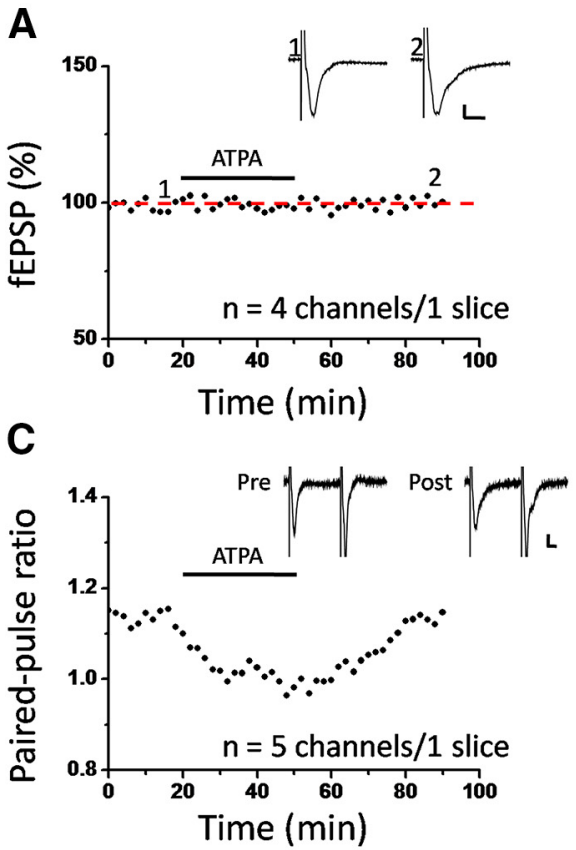

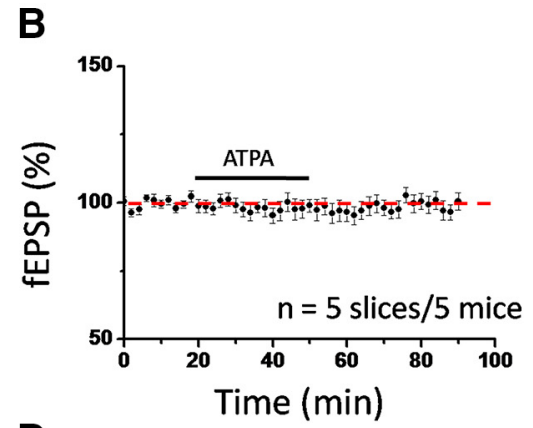

D

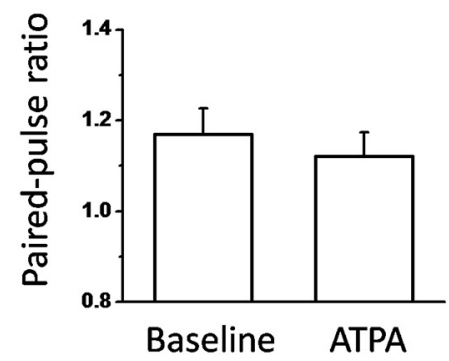

Figure 6. ATPA alone cannot induce cingulate pre-LTP at the network level.) ATPA (1 $\mu \mathrm{m})$ was bath applied for $30 \mathrm{~min}$ without low-frequency stimulation delivery. Results of four channels in one slice (averaged data of 4 channels) showed the failure of pre-LTP induction. $\boldsymbol{B}$, Pooled data from five slices of five mice. $\boldsymbol{C}$, PPR remains unaffected by ATPA alone in one slice (averaged data of 5 channels). D, Bar histogram showing the pooled data of PPR from five slices of five mice. Insets in $\boldsymbol{A}$ show representative fEPSP traces at time points indicated by the numbers in the graph. Sample traces in C are paired-pulse responses before (Pre) and $40 \mathrm{~min}$ after ATPA (Post). Calibration, $100 \mu \mathrm{V}, 10 \mathrm{~ms}$. Error bars are SEM. 
A

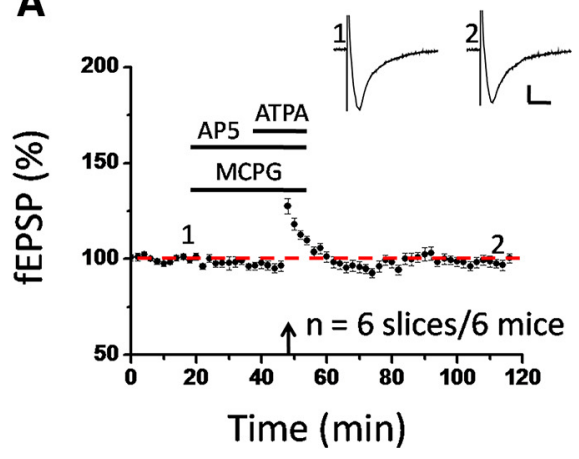

C

\section{Activated channels}

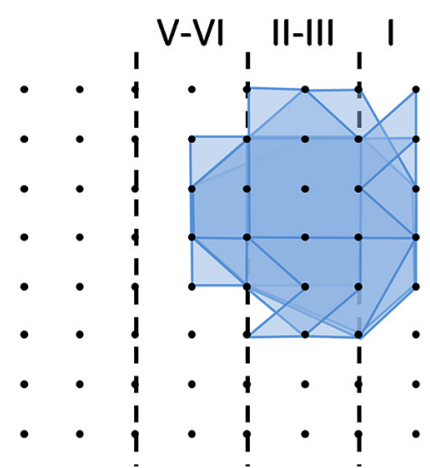

B

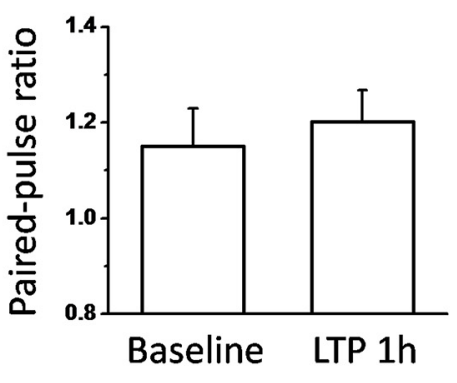

D LTP-showing channels

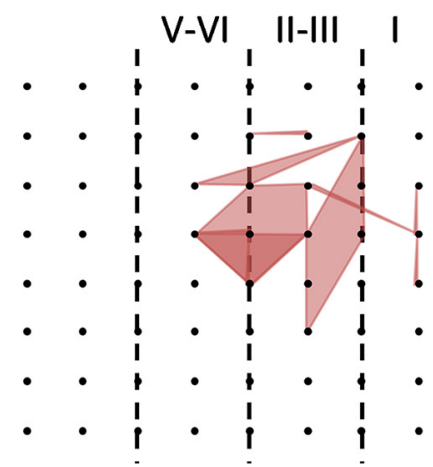

Figure 7. Network cingulate pre-LTP requires mGluR activation. $A$, An mGluR antagonist, MCPG $(500 \mu \mathrm{M})$, was applied together with AP5 $(50 \mu \mathrm{M})$ for the duration of pre-LTP process. MCPG blocked the pre-LTP induction ( $n=6$ slices $/ 6$ mice). $B$, Summary graph showing the lack of change in PPR. C, D, Polygonal diagrams of the channels that are activated in the baseline (blue, $C$ ) and that undergo pre-LTP (red, $\boldsymbol{D})$ in six slices from six mice. The numbers of pre-LTP-showing channels was greatly decreased. Insets in $A$ show representative fEPSP traces at time points indicated by the numbers in the graph. Calibration, $100 \mu V, 10 \mathrm{~ms}$. Error bars are SEM.

LTP during the entire recording period of $1 \mathrm{~h}(102 \pm 3 \%$ of baseline, $n=6$ slices $/ 5$ mice, paired $t$ test, $p>0.05$ compared with baseline; Fig. $8 B$ ). No appreciable changes were observed in the PPR following low-frequency stimulation in the Fmr1 KO mice (baseline vs $1 \mathrm{~h}$ after low-frequency stimulation: $1.2 \pm 0.1 \mathrm{vs}$ $1.2 \pm 0.1, n=6$ slices $/ 5$ mice, $p>0.05$ compared with baseline; Fig. $8 C, D)$. Finally, spatial analysis show a great reduction of LTP-occurring channels compared with the activated channels in the ACC (Fig. 8E,F). Among the six slices analyzed, 109 channels (mean \pm SEM: $18 \pm 1$ ) were activated, but only 25 channels (mean \pm SEM: $4 \pm 1$ ) exhibited pre-LTP (induction ratio: $24 \pm$ $7 \%, n=6$ slices/5 mice). Together, these data indicate that Fmr1 deletion blocked the induction of network pre-LTP in the ACC.

\section{Fmr1 KO mice show normal expression of synapsin I in the ACC}

Previously, we show that the basal synaptic transmission is normal in the ACC of Fmr1 KO mice (Zhao et al., 2005). It has been reported that FMRP regulates the expression of many presynaptic molecules (Liao et al., 2008). Synapsin I is one of the major presynaptic molecules expressed in the whole brain (Südhof, 1990). Synapsin I can regulate basal synaptic transmission but not LTP (Spillane et al., 1995). Therefore, we addressed the possible regulation of synapsin I expression in the ACC using immunoblot analysis. Synapsin I was detected in both homogenate and synaptosomal fractions of the ACC (Fig. 9A). There were no significant differences in the abundance of synapsin I between FmrI WT and Fmr1 KO mice in either homogenate (111 $\pm 3 \%$ in Fmr1
KO mice compared with Fmr1 WT mice, $n=3$ for each group, $p>0.05$; Fig. $9 B$ ) or synaptosome (104 $\pm 3 \%$ in Fmr1 KO mice compared with Fmr1 WT mice, $n=$ 3 for each group, $p>0.05$; Fig. 9B). These results suggest that expression or synaptic localization of synapsin I is unchanged in the ACC by Fmr1 deletion.

\section{Fmr1 KO mice show altered translocation of PKA subunits in the ACC}

We further explored the possible mechanisms of abolished pre-LTP in the Fmr1 $\mathrm{KO}$ mice. PKA is known to regulate LTP both postsynaptically (Esteban et al., 2003; Nguyen and Woo, 2003) and presynaptically (Huang et al., 1995; Fourcaudot et al., 2009; Koga et al., 2015). The PKA holoenzyme is a tetrameric complex consisting of a dimer of regulatory (RI, RII) and two catalytic (C) subunits. Whereas RII $\alpha$ expression is ubiquitous, RII $\beta$ is found predominantly in the brain (Skalhegg and Tasken, 2000). PKA is anchored mainly through A-kinase anchoring proteins (AKAPs) (Pidoux and Taskén, 2010). We thus examined whether FMRP may modulate PKA subunits or AKAPs in the ACC. We tested the protein expression levels of these molecules in three different fractions (homogenate, cytosome, and synaptosome) from Fmrl WT and KO mice (Fig. 9C). We found that the abundance of PKA-C, RII $\alpha, \operatorname{RII} \beta$ and AKAP79/150 showed no changes in the homogenate (Homo) from Fmr1 KO mice compared with WT mice (Fmr1 KO mice: $103 \pm 4 \%$ for PKA-C, $101 \pm 3 \%$ for PKA-RII $\alpha, 96 \pm 3 \%$ for PKA-RII $\beta, 99.0 \pm 4 \%$ for AKAP79/150, $n=3$ for each group; Fig. 9D). Furthermore, no change was observed for the abundance of PKA-RII $\alpha$ and AKAP79/150 in the cytosome (S2) or synaptosome (P2) between Fmr1 WT and Fmr1 KO mice (Fig. $9 E, F)$. However, we found that the amount of PKA-C was significantly enhanced in the cytosolic fraction but decreased in the synaptosomal fraction (S2 in Fmr1 KO mice: $123.0 \pm 5.0 \%$, P2 in Fmr1 KO mice: $82.0 \pm 3.0 \%, n=3$ for each group; Fig. $9 E, F)$. Moreover, the expression of PKA-RII $\beta$ was significantly decreased in the synaptosome of Fmr1 KO mice compared with WT mice (P2 in Fmr1 KO mice: $85.0 \pm 6.0 \%, n=3$ for each group; Fig. $9 F$ ). These results suggest that FMRP can affect the location of specific PKA subunits across the synapse in the ACC.

\section{Discussion}

In this study, we identified two forms of cortical pre-LTP in the adult mouse ACC by using both whole-cell patch-clamp recordings and 64-channel field potential recordings. The newly established pre-LTP requires L-VGCC, kainate, or mGluR activation in the induction process. Interestingly, Fmr1 KO mice failed to produce both types of pre-LTP in the ACC. We also revealed that Fmr1 KO mice showed altered translocations of certain PKA subunits, which might contribute partially to the loss of cingulate pre-LTP. 
Recordings of pre-LTP in the ACC

Presynaptically expressed forms of LTP have been well documented in the hippocampus and amygdala (Bortolotto et al., 1999; Nicoll and Schmitz, 2005; Shin et al., 2010). However, this is the first time to induce cingulate pre-LTP from adult mice. Whole-cell patch-clamp recordings revealed that low-frequency stimulation produced significant LTP associated with changes in PPR. This novel form of cingulate LTP is similar as one previous study in the amygdala (Shin et al., 2010). The pre-LTP in the amygdala requires GluK1containing kainate receptor and is independent of NMDA receptor. L-VGCCs are also required for the induction of this pre-LTP, which is in line with previous publications in hippocampus and amygdala (Lauri et al., 2003; Fourcaudot et al., 2009).

By using the previously established multichannel fEPSP recording system (Kang et al., 2012; Liu et al., 2013a,b), we further demonstrate that combinations of low-frequency stimulation $(2 \mathrm{~Hz}, 2 \mathrm{~min}$ ) with a GluK1 receptor agonist (ATPA, 1 $\mu \mathrm{M})$ could also produce a presynaptic form of cingulate LTP at the network level, spreading to both superficial and deep layers of the ACC. Both lowfrequency stimulation delivery and ATPA application are required for the induction of cingulate pre-LTP because low-frequency stimulation or ATPA alone failed to produce any potentiation. The pre-LTP induced by the combination protocol of low-frequency stimulation and ATPA was NMDA receptor-independent, but mGluRdependent. These results are similar to previous observations in the hippocampal synapses, where synergistic interactions between kainate receptor and mGluR are needed for the full induction of mossy fiber pre-LTP (Nisticò et al., 2011). We are currently investigating whether this glutamate receptor interaction rule also applies to the cingulate pre-LTP we observed in the present study. Together, we provide the first report of pre-LTP recordings in the ACC at both neuronal and network levels.

\section{Loss of pre-LTP in Fmr1 KO mice}

The role of FMRP in LTP has been extensively studied in the hippocampal CA1 region. However, controversy still exists regarding the exact contribution of FMRP to hippocampal LTP (Mercaldo et al., 2009; Sidorov et al., 2013). Although some previous studies demonstrated the impairment of CA1 LTP in Fmr1 KO mice (Hu et al., 2008; Shang et al., 2009), other reports show the normal induction of LTP (Godfraind et al., 1996; Paradee et al., 1999; Li et al., 2002). With respect to the ACC, our previous works clearly demonstrate the loss of cingulate post-LTP with both whole-cell patch-clamp and 64-channel field potential recordings (Zhao et al., 2005; Chen et al., 2014b). In this study, we
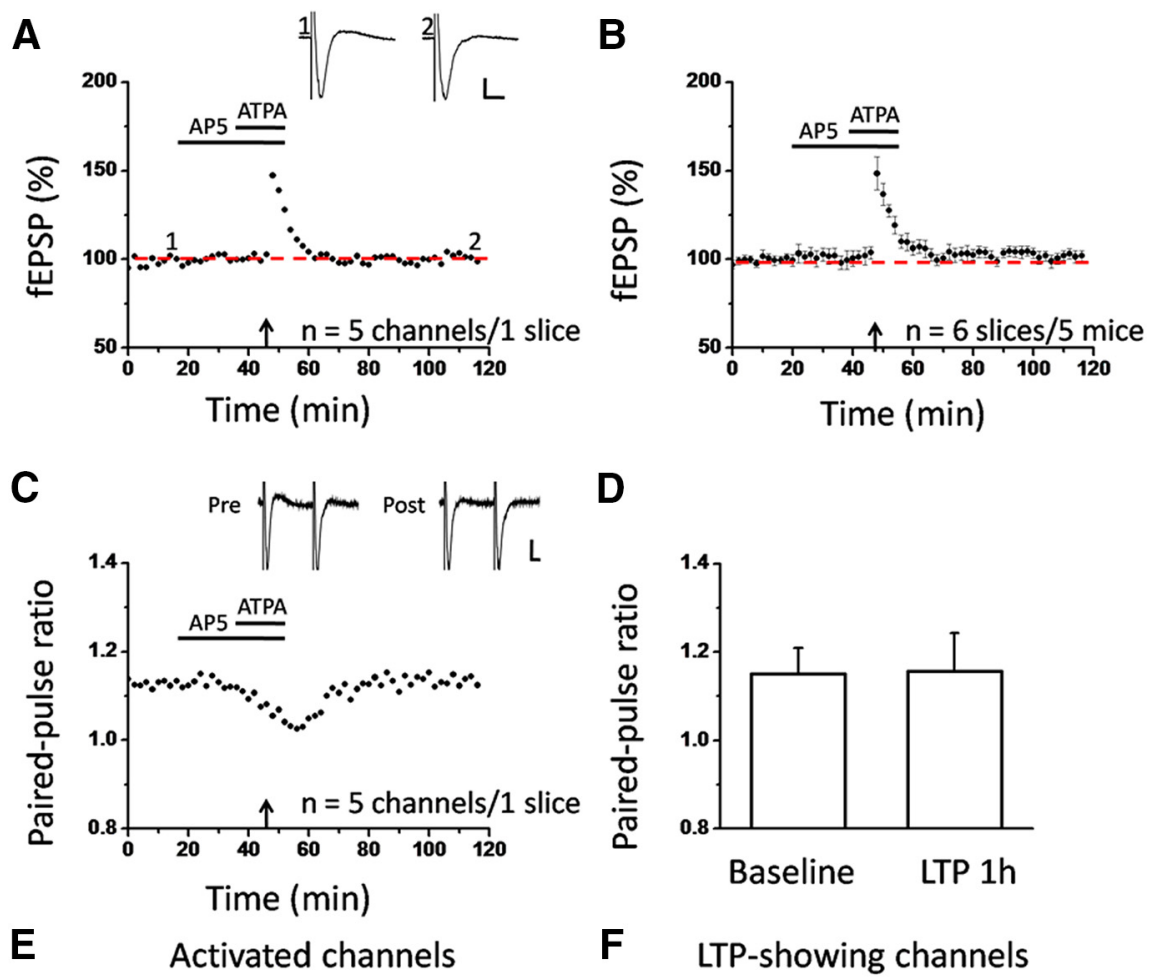

Figure 8. Impairment of network pre-LTP in the ACC of $F m r 1 \mathrm{KO}$ mice. $A$, The low-frequency stimulation $(2 \mathrm{~Hz}, 2 \mathrm{~min})$ combined with ATPA (1 $\mu \mathrm{M}, 18 \mathrm{~min}$ ) could not induce pre-LTP in one slice (averaged data of 5 channels) taken from Fmr $1 \mathrm{KO}$ mice. B, Pooled 5 channels). D, Bar histogram showing the pooled data of PPR from six slices of five mice. $\boldsymbol{E}, \boldsymbol{F}$, Polygonal diagrams of the channels that are activated in the baseline (blue, $\boldsymbol{E}$ ) and that undergo pre-LTP $($ red, $\boldsymbol{F}$ ) in six slices from five mice. The numbers of numbers in the graph. Sample traces in Care paired-pulse responses before (Pre) and $1 \mathrm{~h}$ after pre-LTP induction (Post). Calibration, $50 \mu \mathrm{V}, 10 \mathrm{~ms}$. Error bars are SEM.

further demonstrate that the cingulate pre-LTP is equally sensitive to the Fmr1 deletion. We identified two forms of pre-LTP in the ACC and both of them are blocked in the Fmrl KO mice. Not only the induction probability but also the spatial distribution maps of pre-LTP-undergoing channels are greatly reduced. Together, these results suggest that failure to induce the cortical LTP might be a common synaptic deficit presented in the Fmrl KO mice.

Mechanisms underlying the loss of pre-LTP in Fmr1 KO mice It is still unclear as to the mechanisms underlying the deficiency of cortical pre-LTP in Fmrl KO mice. One possible explanation may be that Fmr1 deletion leads to alterations in the PKA signaling pathway or other presynaptic molecules. Synapsin I is an important presynaptic molecule playing critical roles in basal synaptic transmission, but not in LTP (Rosahl et al., 1993). Based 
A

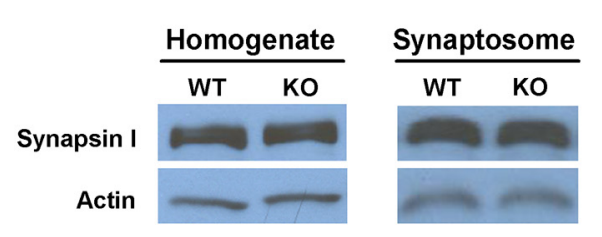

C

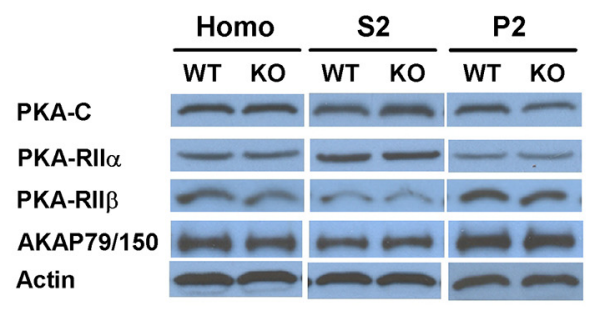

E

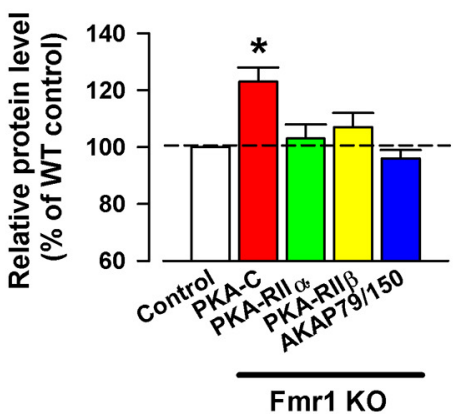

B

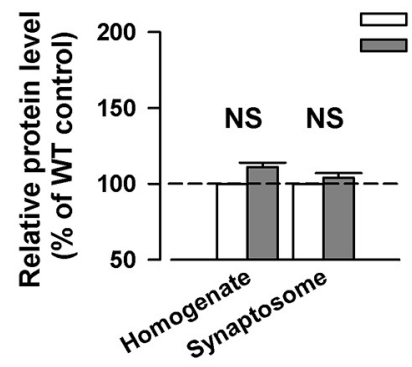

D

Homogenate

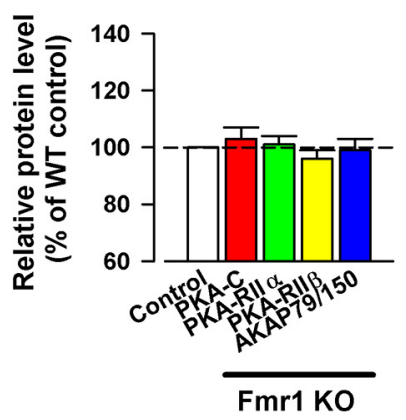

$\mathbf{F}$

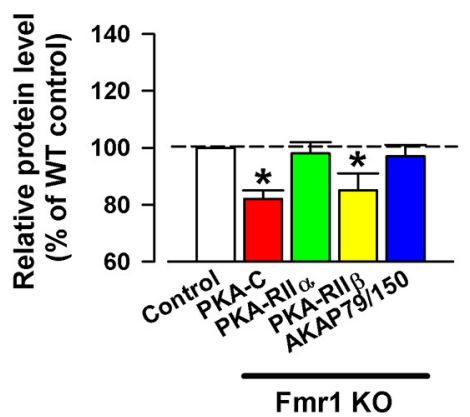

Figure 9. Biochemical analysis of expression of synapsin I and protein kinase A (PKA) subunits in the ACC of Fmr 1 WT and Fmr 1 KO mice. $\boldsymbol{A}$, Representative Western blots for synapsin I in the homogenate and synaptosome fraction of the ACC obtained from Fmr 1 WT and Fmr 1 KO mice. $B$, The expression levels of synapsin I in the homogenate and synaptosome did not change between Fmr 1 WT and Fmr 1 KO mice ( $n=3$ mice for each group). C, Representative Western blots for PKA catalytic subunits (PKA-C), PKA regulatory II subunits (PKA-RII, RII), and A-kinase anchoring proteins (AKAP79/150) in the homogenate (H), crude synaptosomal membrane (P2), and cytosome (S2) fractions of the ACC obtained from Fmr 1 WT and Fmr 1 KO mice. D, The amount of all tested proteins did not differ between Fmr1 WT and Fmr1 K0 mice ( $n=3$ mice for each group). $\boldsymbol{E}$, The expression of PKA-C was significantly increased in the cytosome in Fmr $1 \mathrm{KO}$ mice compared with Fmr 1 WT mice ( $n=3$ mice for each group). $\boldsymbol{F}$, The synaptic amount of PKA-C and PKA-RII $\beta$ was significantly decreased in Fmr 1 KO mice compared with Fmr 1 WT mice ( $n=3$ mice for each group). Error bars are SEM; * $p<0.05$. NS indicates no significant difference.

on the contribution of FMRP to presynaptic signaling (Deng et al., 2013; Wang et al., 2014), we examined changes in the expression of synapsin I in the ACC. We found that Fmr1 KO mice displayed normal protein expression level of synapsin I in either homogenate or synaptosomal fractions. This result can be interpreted as supporting the previous data showing the normal basal synaptic transmission in the ACC of Fmrl KO mice (Zhao et al., 2005).

PKA-dependent pathways are critical for post-LTP in the ACC (Zhuo, 2008). The cingulate pre-LTP also requires PKA activation (Koga et al., 2015). In our biochemical analysis, we found that total expression of all tested PKA subunits and AKAPs did not change, whereas the synaptic amounts of PKA-C and PKA-RII $\beta$ were significantly decreased in the ACC of Fmr1 KO mice. Alterations in the subcellular localization of PKA subunits may induce the loss of preLTP. Indeed, genetic ablation of PKA-C or PKA-R has been reported to reduce the magnitude of mossy fiber pre-LTP (Huang et al., 1995). Therefore, we reasoned that the translocation of PKA subunits in Fmr1 KO mice might cause changes in PKA activity, thus resulting in loss of pre-LTP in the ACC. We would like to point out that biochemical analysis is based on global changes in the synaptosomal fraction; we cannot exclude the possibility that other mechanisms might also be involved in this process. For example, Fmr1 deletion may affect the expression or function of other presynaptic molecules that are critical for pre-LTP. Liao et al. (2008) demonstrate that the mRNA levels of Munc 13-1 and synaptophysin are remarkably decreased in the Fmr1 KO mice (Liao et al., 2008). Lack of those molecules results in abnormal mossy fiber LTP in the hippocampus (Janz et al., 1999; Yang and Calakos, 2011). It is thus reasonable to speculate that a similar mechanism may underlie the blockade of pre-LTP in the ACC. Other ion channels related to neurotransmitter release can also be regulated by FMRP either directly or indirectly. For example, FMRP directly regulates the large conductance $\mathrm{Ca}^{2+}$-activated $\mathrm{K}^{+}$channels, which in turn affects the duration of the action potentials and the subsequent presynaptic $\mathrm{Ca}^{2+}$ influx (Deng et al., 2013). FMRP can also increase the expression density of VGCCs in the presynaptic terminals (Ferron et al., 2014). The mRNA level of L-VGCC subunits was markedly decreased in the neocortex of Fmr1 KO mice (Liao et al., 2008). Notably, L-VGCC is necessary for the induction of pre-LTP in the ACC (this study). Therefore, dysfunctions of other presynaptic molecules or ion channels might be might be an alternative mechanism for the loss of pre-LTP in Fmrl KO mice. Future studies are required to address this issue in more detail.

\section{Functional implications}

It is well known that ACC plays important roles in pain, learning/ memory and emotional processing (Frankland et al., 2004; Zhuo, 2008, 2014). Fmr1 KO mice often display learning deficits and anxiety-like behaviors (Zhao et al., 2005; Mineur et al., 2006; Guo et al., 2012). Because LTP is widely thought to be correlated to learning and memory (Bliss and Collingridge, 1993), we hypothesize that the loss of long-term plasticity in both presynapses and 
postsynapses in the ACC may constitute an essential mechanism for the behavioral deficits observed in the Fmr1 KO mice. Future experiments are certainly warranted to further determine the behavioral relevance of pre-LTP in the ACC and the pathological significance of its changes in the Fmr1 KO mice. In summary, we report for the first time the recording of pre-LTP in the adult mouse ACC. Fmr1 KO mice exhibited loss of cingulate pre-LTP induction, accompanied by alterations in the translocation of PKA subunits across the synapse. These results provide better understanding of the synaptic basis for the pathophysiology of FXS and suggest that cortical pre-LTP deficit may emerge as a novel target for the improvement of the FXS therapy.

\section{References}

Akins MR, Leblanc HF, Stackpole EE, Chyung E, Fallon JR (2012) Systematic mapping of fragile $\mathrm{X}$ granules in the mouse brain reveals a potential role for presynaptic FMRP in sensorimotor functions. J Comp Neurol 520:3687-3706. CrossRef Medline

Bagni C, Greenough WT (2005) From mRNP trafficking to spine dysmotphogenesis: the roots of fragile X syndrome. Nat Rev Neurosci 6:376-387. CrossRef Medline

Bhakar AL, Dölen G, Bear MF (2012) The pathophysiology of fragile X (and what it teaches us about synapses). Annu Rev Neurosci 35:417-443. CrossRef Medline

Bliss TV, Collingridge GL (1993) A synaptic model of memory: long-term potentiation in the hippocampus. Nature 361:31-39. CrossRef Medline

Bliss TV, Collingridge GL (2013) Expression of NMDA receptor-dependent LTP in the hippocampus: bridging the divide. Mol Brain 6:5. CrossRef Medline

Bortolotto ZA, Clarke VR, Delany CM, Parry MC, Smolders I, Vignes M, Ho KH, Miu P, Brinton BT, Fantaske R, Ogden A, Gates M, Ornstein PL, Lodge D, Bleakman D, Collingridge GL (1999) Kainate receptors are involved in synaptic plasticity. Nature 402:297-301. CrossRef Medline

Chen T, O’Den G, Song Q, Koga K, Zhang MM, Zhuo M (2014a) Adenylyl cyclase subtype 1 is essential for late-phase long term potentiation and spatial propagation of synaptic responses in the anterior cingulate cortex of adult mice. Mol Pain 10:65. CrossRef Medline

Chen T, Lu JS, Song Q, Liu MG, Koga K, Descalzi G, Li YQ, Zhuo M (2014b) Pharmacological rescue of cortical synaptic and network potentiation in a mouse model for fragile X syndrome. Neuropsychopharmacology 39: 1955-1967. CrossRef Medline

Christie SB, Akins MR, Schwob JE, Fallon JR (2009) The FXG: a presynaptic fragile $\mathrm{X}$ granule expressed in a subset of developing brain circuits. J Neurosci 29:1514-1524. CrossRef Medline

Deng PY, Sojka D, Klyachko VA (2011) Abnormal presynaptic short-term plasticity and information processing in a mouse model of fragile $\mathrm{X}$ syndrome. J Neurosci 31:10971-10982. CrossRef Medline

Deng PY, Rotman Z, Blundon JA, Cho Y, Cui J, Cavalli V, Zakharenko SS, Klyachko VA (2013) FMRP regulates neurotransmitter release and synaptic information transmission by modulating action potential duration via BK channels. Neuron 77:696-711. CrossRef Medline

Descalzi G, Chen T, Koga K, Li XY, Yamada K, Zhuo M (2013) Cortical GluK1 kainate receptors modulate scratching in adult mice. J Neurochem 126:636-650. CrossRef Medline

Esteban JA, Shi SH, Wilson C, Nuriya M, Huganir RL, Malinow R (2003) PKA phosphorylation of AMPA receptor subunits controls synaptic trafficking underlying plasticity. Nat Neurosci 6:136-143. CrossRef Medline

Ferron L, Nieto-Rostro M, Cassidy JS, Dolphin AC (2014) Fragile X mental retardation protein controls synaptic vesicle exocytosis by modulating N-type calcium channel density. Nat Commun 5:3628. CrossRef Medline

Fourcaudot E, Gambino F, Casassus G, Poulain B, Humeau Y, Lüthi A (2009) L-type voltage-dependent $\mathrm{Ca}(2+)$ channels mediate expression of presynaptic LTP in amygdala. Nat Neurosci 12:1093-1095. CrossRef Medline

Frankland PW, Bontempi B, Talton LE, Kaczmarek L, Silva AJ (2004) The involvement of the anterior cingulate cortex in remote contextual fear memory. Science 304:881-883. CrossRef Medline

Godfraind JM, Reyniers E, De Boulle K, D’Hooge R, De Deyn PP, Bakker CE, Oostra BA, Kooy RF, Willems PJ (1996) Long-term potentiation in the hippocampus of fragile X knockout mice. Am J Med Genet 64:246-251. CrossRef Medline
Guo W, Murthy AC, Zhang L, Johnson EB, Schaller EG, Allan AM, Zhao X (2012) Inhibition of GSK3 $\beta$ improves hippocampus-dependent learning and rescues neurogenesis in a mouse model of fragile $\mathrm{X}$ syndrome. Hum Mol Genet 21:681-691. CrossRef Medline

Hu H, Qin Y, Bochorishvili G, Zhu Y, van Aelst L, Zhu JJ (2008) Ras signaling mechanisms underlying impaired GluR1-dependent plasticity associated with fragile X syndrome. J Neurosci 28:7847-7862. CrossRef Medline

Huang YY, Kandel ER, Varshavsky L, Brandon EP, Qi M, Idzerda RL, McKnight GS, Bourtchouladze R (1995) A genetic test of the effects of mutations in PKA on mossy fiber LTP and its relation to spatial and contextual learning. Cell 83:1211-1222. CrossRef Medline

Janz R, Südhof TC, Hammer RE, Unni V, Siegelbaum SA, Bolshakov VY (1999) Essential roles in synaptic plasticity for synaptogyrin I and synaptophysin I. Neuron 24:687-700. CrossRef Medline

Kandel ER (2012) The molecular biology of memory: cAMP, PKA, CRE, CREB-1, CREB-2, and CPEB. Mol Brain 5:14. CrossRef Medline

Kang SJ, Liu MG, Chen T, Ko HG, Baek GC, Lee HR, Lee K, Collingridge GL, Kaang BK, Zhuo M (2012) Plasticity of metabotropic glutamate receptor-dependent long-term depression in the anterior cingulate cortex after amputation. J Neurosci 32:11318-11329. CrossRef Medline

Kang SJ, Liu MG, Shi TY, Zhao MG, Kaang BK, Zhuo M (2013) N-type voltage gated calcium channels mediate excitatory synaptic transmission in the anterior cingulate cortex of adult mice. Mol Pain 9:58. CrossRef Medline

Koga K, Descalzi G, Chen T, Ko H.G, Lu J, Li S, Son J, Kim TH, Kwak C, Huganir RL, Zhao MG, Kaang BK, Collingridge GL, Zhuo M (2015) Co-existence of two forms of LTP in ACC provides a synaptic mechanism for the interactions between anxiety and chronic pain. Neuron, in press.

Lauri SE, Bortolotto ZA, Nistico R, Bleakman D, Ornstein PL, Lodge D, Isaac JT, Collingridge GL (2003) A role for $\mathrm{Ca} 2+$ stores in kainate receptordependent synaptic facilitation and LTP at mossy fiber synapses in the hippocampus. Neuron 39:327-341. CrossRef Medline

Li J, Pelletier MR, Perez Velazquez JL, Carlen PL (2002) Reduced cortical synaptic plasticity and GluR1 expression associated with fragile X mental retardation protein deficiency. Mol Cell Neurosci 19:138-151. CrossRef Medline

Liao L, Park SK, Xu T, Vanderklish P, Yates JR 3rd (2008) Quantitative proteomic analysis of primary neurons reveals diverse changes in synaptic protein content in fmrl knockout mice. Proc Natl Acad Sci U S A 105: 15281-15286. CrossRef Medline

Liu MG, Zhuo M (2014) No requirement of TRPV1 in long-term potentiation or long-term depression in the anterior cingulate cortex. Mol Brain 7:27. CrossRef Medline

Liu MG, Koga K, Guo YY, Kang SJ, Collingridge GL, Kaang BK, Zhao MG, Zhuo M (2013a) Long-term depression of synaptic transmission in the adult mouse insular cortex in vitro. Eur J Neurosci 38:3128-3145. CrossRef Medline

Liu MG, Kang SJ, Shi TY, Koga K, Zhang MM, Collingridge GL, Kaang BK, Zhuo M (2013b) Long-term potentiation of synaptic transmission in the adult mouse insular cortex: multielectrode array recordings. J Neurophysiol 110:505-521. CrossRef Medline

Mercaldo V, Descalzi G, Zhuo M (2009) Fragile X mental retardation protein in learning-related synaptic plasticity. Mol Cells 28:501-507. CrossRef Medline

Mineur YS, Huynh LX, Crusio WE (2006) Social behavior deficits in the Fmr1 mutant mouse. Behav Brain Res 168:172-175. CrossRef Medline

Nguyen PV, Woo NH (2003) Regulation of hippocampal synaptic plasticity by cyclic AMP-dependent protein kinases. Prog Neurobiol 71:401-437. CrossRef Medline

Nicoll RA, Schmitz D (2005) Synaptic plasticity at hippocampal mossy fibre synapses. Nat Rev Neurosci 6:863-876. CrossRef Medline

Nisticò R, Dargan SL, Amici M, Collingridge GL, Bortolotto ZA(2011) Synergistic interactions between kainate and mGlu receptors regulate bouton Ca signalling and mossy fibre LTP. Sci Rep 1:103. CrossRef Medline

Paradee W, Melikian HE, Rasmussen DL, Kenneson A, Conn PJ, Warren ST (1999) Fragile X mouse: strain effects of knockout phenotype and evidence suggesting deficient amygdala function. Neuroscience 94:185-192. CrossRef Medline

Pidoux G, Taskén K (2010) Specificity and spatial dynamics of protein kinase A signaling organized by A-kinase-anchoring proteins. J Mol Endocrinol 44:271-284. CrossRef Medline 
Qiu S, Chen T, Koga K, Guo YY, Xu H, Song Q, Wang JJ, Descalzi G, Kaang BK, Luo JH, Zhuo M, Zhao MG (2013) An increase in synaptic NMDA receptors in the insular cortex contributes to neuropathic pain. Sci Signal 6:ra34. CrossRef Medline

Qiu S, Zhang M, Liu Y, Guo Y, Zhao H, Song Q, Zhao M, Huganir RL, Luo J, $\mathrm{Xu} \mathrm{H}$, Zhuo M (2014) GluAl phosphorylation contributes to postsynaptic amplification of neuropathic pain in the insular cortex. J Neurosci 34:13505-13515. CrossRef Medline

Rosahl TW, Geppert M, Spillane D, Herz J, Hammer RE, Malenka RC, Südhof TC (1993) Short-term synaptic plasticity is altered in mice lacking synapsin I. Cell 75:661-670. CrossRef Medline

Santoro MR, Bray SM, Warren ST (2012) Molecular mechanisms of fragile X syndrome: a twenty-year perspective. Annu Rev Pathol 7:219-245. CrossRef Medline

Shang Y, Wang H, Mercaldo V, Li X, Chen T, Zhuo M (2009) Fragile X mental retardation protein is required for chemically-induced long-term potentiation of the hippocampus in adult mice. J Neurochem 111:635646. CrossRef Medline

Shin RM, Tully K, Li Y, Cho JH, Higuchi M, Suhara T, Bolshakov VY (2010) Hierarchical order of coexisting pre- and postsynaptic forms of long-term potentiation at synapses in amygdala. Proc Natl Acad Sci U S A 107: 19073-19078. CrossRef Medline

Sidorov MS, Auerbach BD, Bear MF (2013) Fragile X mental retardation protein and synaptic plasticity. Mol Brain 6:15. CrossRef Medline

Skalhegg BS, Tasken K (2000) Specificity in the cAMP/PKA signaling pathway: differential expression, regulation, and subcellular localization of subunits of PKA. Front Biosci 5:D678-D693. CrossRef Medline

Spillane DM, Rosahl TW, Südhof TC, Malenka RC (1995) Long-term po- tentiation in mice lacking synapsins. Neuropharmacology 34:1573-1579. CrossRef Medline

Südhof TC (1990) The structure of the human synapsin I gene and protein. J Biol Chem 265:7849-7852. Medline

Wang H, Wu LJ, Kim SS, Lee FJ, Gong B, Toyoda H, Ren M, Shang YZ, Xu H, Liu F, Zhao MG, Zhuo M (2008) FMRP acts as a key messenger for dopamine modulation in the forebrain. Neuron 59:634-647. CrossRef Medline

Wang XS, Peng CZ, Cai WJ, Xia J, Jin D, Dai Y, Luo XG, Klyachko VA, Deng PY (2014) Activity-dependent regulation of release probability at excitatory hippocampal synapses: a crucial role of fragile $\mathrm{X}$ mental retardation protein in neurotransmission. Eur J Neurosci 39:1602-1612. CrossRef Medline

Yang Y, Calakos N (2011) Munc13-1 is required for presynaptic long-term potentiation. J Neurosci 31:12053-12057. CrossRef Medline

Zang T, Maksimova MA, Cowan CW, Bassel-Duby R, Olson EN, Huber KM (2013) Postsynaptic FMRP bidirectionally regulates excitatory synapses as a function of developmental age and MEF2 activity. Mol Cell Neurosci 56:39-49. CrossRef Medline

Zhao MG, Toyoda H, Ko SW, Ding HK, Wu LJ, Zhuo M (2005) Deficits in trace fear memory and long-term potentiation in a mouse model for fragile X syndrome. J Neurosci 25:7385-7392. CrossRef Medline

Zhuo M (2008) Cortical excitation and chronic pain. Trends Neurosci 31: 199-207. CrossRef Medline

Zhuo M (2014) Long-term potentiation in the anterior cingulate cortex and chronic pain. Philos Trans R Soc Lond B Biol Sci 369:20130146. CrossRef Medline

Zucker RS, Regehr WG (2002) Short-term synaptic plasticity. Annu Rev Physiol 64:355-405. CrossRef Medline 